Vol. 1, No. 2, Mei 2020, pp. 60-67

\title{
IMPLEMENTASI SENTRA BERMAIN PERAN DALAM \\ PEMBELAJARAN BAHASA ANAK DI PAUD AL AMIN PRINGGODANI BANTUR-MALANG
}

\author{
Uswatul Hasanah \\ PAUD Al-Amin \\ uus.6mei@gmail.com
}

\section{Info Artikel}

Riwayat Artikel

Diterima : 30 April 2020

Disetujui : 25 Mei 2020

\section{Kata Kunci :}

Sentra Bermain Peran,

Pembelajaran Bahasa

\begin{abstract}
ABSTRAK
Abstract: The ability of teachers to manage role playing learning is one of the attractions of children who can affect children's language skills. The purpose of this study is to describe the implementation of the role playing center, the role of the teacher, and the process of language learning through the technique of using an early childhood role playing center. The research method is descriptive-qualitative. Data collection techniques such as interviews, observation, and documents. The findings obtained include preparing a role playing learning plan, role playing activities require the full involvement of children, especially in the space and time of its application and the role of the teacher in building creative learning to improve children's language skills. This study concluded that the process of developing language skills in children is not enough to be done only once in the role playing learning center. Instead, it needs to be done repeatedly in the process of applying it by determining the themes in learning center playing roles differently. Thus, the role of the teacher is very important in building creativity in managing learning in the classroom.
\end{abstract}

Abstrak: Kemampuan guru dalam mengelolah pembelajaran bermain peran menjadi salah satu daya tarik anak yang dapat mempengaruhi kemampuan bahasa anak. Tujuan penelitian ini untuk mendeskripsikan implementasi sentra bermain peran, peran guru, dan proses pembelajaran bahasa melalui teknik penggunaan sentra bermain peran anak usia dini. Metode penelitian berupa deskriptif-kualitatif. Teknik pengumpulan data berupa wawancara, observasi, dan dokumen. Hasil temuan yang di peroleh meliputi mempersiapkan rancangan pembelajaran bermain peran, kegiatan bermain peran membutuhkan keterlibatan anak secara penuh terutama pada ruang dan waktu penerapannya dan peran serta guru dalam membangun pembelajaran secara kreatif untuk meningkatkan kemampuan bahasa anak. Penelitian ini disimpulkan proses perkembangan kemampuan bahasa pada anak tidak cukup dilakukan hanya satu kali dalam pembelajaran sentra bermain peran. Melainkan, perlu dilakukan berulang-ulang kali dalam proses penerapannya dengan menentukan tema dalam pembelajaran sentra bermain peran secara berbeda. Sehingga, peran serta guru sangat penting dalam membangun kreatifitas dalam mengelolah pembelajaran di dalam kelas. 


\section{PENDAHULUAN}

Masa perkembangan anak usia dini merupakan waktu yang sangat ideal untuk memberikan stimulasi kegiatan guna merangsang aspek perkembangan anak sebagai program pendidikan awal. Pendidikan awal anak mengarah pada pembentukan kemampuan pengetahuan, kemampuan sikap dan kemampuan keterampilan anak. Selain itu, kebermaknaanya terhadap kemampuan dapat mengeksplorasi berbagai imajinasinya dari pemikirannya untuk mengembangkan interaksi di dalam lingkungan belajar sekolah.

Pendidikan anak usia dini (PAUD) merupakan pendidikan yang diselenggarakan dengan tujuan untuk memfasilitasi pertumbuhan dan perkembangan anak secara menyeluruh atau menekankan pada seluruh aspek perkembangan yang di miliki anak untuk memunculkan potensi secara optimal. Konsekuensinya, lembaga PAUD perlu menyediakan berbagai kegiatan yang dapat mengembangan aspek perkembangan. Dimana, aspek perkembangan meliputi aspek nilai moral agama, aspek sosial emosional, aspek kognitif, aspek fisik motorik, aspek bahasa, dan aspek seni ${ }^{1}$. Namun, peneliti memfokuskan pada aspek kemampuan bahasa anak.

Kemampuan bahasa merupakan sarana komunikasi melalui pikiran dan perasaan untuk menyampaikan pesan kepada orang lain. Kemahiran berbahasa anak dapat di lihat dari banyaknya anak meniru lawan bicaranya. Karena berbicara dengan orang lain dapat menambah kata-kata baru dan memahami cara mengkomunikasikan kata-kata yang baik dalam kalimat yang lebih kompleks. ${ }^{2}$ Seringkali, peneliti melihat anak-anak usia TK sudah dapat berbicara tentang apa yang terjadi disekitarnya. Salah satu jalan bagi mereka untuk menggunakan bahasa dalam ekspresi perasaan. Namun, ada sebagian anak mengalami kesulitan dalam mengungkapkan perasaanya dengan kata-kata dan anak lebih sering menunjukkan dengan perbuatan, terkadang mereka lebih mudah mengekspresikan media berupa boneka dari pada perasaanya sendiri. ${ }^{3}$

Melihat kasus tersebut, berbicara memiliki peran penting dalam kehidupan anak dan memberika pengaruh yang besar bagi kehidupan anak selanjutnya. Anak akan mudah di terima dalam kelompok teman sebayanya apabila anak memiliki ketrampilan berbicara yang baik. Selain itu, berbicara akan memudahkan anak untuk berinteraksi dan berkomunikasi dengan orang tua, guru, teman sebayanya, dan lingkungan disekitarnya. Oleh karena itu, pendidik harus mampu mengoptimalkan ketrampilan berbicara anak untuk mengungkapkan kata-kata melalui kegiatan bermain peran.

PAUD Al Amin merupakan lembaga yang menerapkan metode BCCT (Beyond Center and Circle Time) melalui model pembelajaran sentra sebagai media belajar anak. PAUD Al Amin memiliki 4 sentra yang diterapkan yaitu sentra

\footnotetext{
${ }^{1}$ Suyadi dan maulidia ulfa, Konsep Dasar PAUD,(Bandung:Remaja Rosda Karya,2013),hal.17

${ }^{2}$ Maimunah Hasan, PAUD (Pendidikan Anak Usia Dini),(Yogyakarta, Diva Press,2009),hal.38

${ }^{3}$ E Mulayasa, Manajemen PAUD, (Bandung, PT Remaja Rosakrya, 2012), hal.116
} 
persiapan, sentra peran, sentra balok dan sentra bahan alam. Adapun dari ke empat sentra tersebut sentra peran memiliki kontribusi yang lebih besar terhadap perkembangan bahasa terutama pada ketrampilan berbicara anak.

Berkaitan dengan masalah berkomunikasi secara lisan terhadap guru maupun temannya, anak-anak dapat mengekspresikan gagasan atau ide dengan kata-kata, dan sudah mampu mengungkapkan sebuah pesan misalnya ketika melihat temannya membuang sampah sembarangan, seorang anak menegur dan berkata "kamu kok buang sampah sembarangan, kata ibu guru kalau mau buang sampah ke tempat sampah". Namun, kegiatan bermain peran ini dapat memberikan stimulus pada anak cenderung pasif ketika mengekspresikan konsep bermainnya, Sehingga, pendidik perlu sekali mengambil langkah yang tepat dalam merancang pembelajaran bermain peran dengan tujuan agar aspek kemampuan anak dapat berkembang secara optimal. Dimana, setiap langkah tersebut memiliki tujuan dalam berkontribusi untuk melatih kemampuan berbicara pada anak yang pasif menjadi aktif.

Adapun tujuan penelitian yang dilakukan untuk mendeskripsikan implementasi sentra bermain peran dalam pembelajaran bahasa anak, untuk mendeskripsikan peran guru dalam implementasi sentra bermain peran untuk perkembangan bahasa anak, dan untuk mendeskripsikan proses pembelajaran bahasa melalui teknik penggunaan sentra bermain peran di PAUD Al Amin Pringgondani Bantur-Malang

\section{METODE}

Penelitian yang dilakukan untuk mendiskripsikan tentang implementasi sentra bermain peran dalam pembelajaran bahasa anak di PAUD Al-Amin. Penelitian ini menggunakan pendekatan kualitatif. Pendekatan kualitatif digunakan untuk mengungkapkan data deskriptif melalui informan yang memahami tentang apa yang dilakukan, dirasakan, dan dialami terhadap fokus penelitian.

Rancangan penelitian yang digunakan adalah studi kasus (case study) untuk mendiskripsikan implementasi sentra bermain peran untuk pembelajaran bahasa anak di PAUD Al-Amin. Kegiatan pembelajaran bahasa yang diterapkan PAUD Al-Amin dengan mengembangkan sentra bermain peran. Sehingga, peneliti menentukan jenis penelitian studi kasus yang telah menjadi salah satu keunikan dalam penelitian untuk mengambarkan proses pembelajaran bahasa dengan konsep bermain peran yang sesuai dengan tahap perkembangan usia anak. Menurut Hanurawan (2016) mengatakan bawah studi kasus merupakan proses analisis secara mendalam atau rinci terhadap suatu objek penelitian yang unit analisisnya bersifat individual. ${ }^{4}$

\footnotetext{
4 Hanurawan, F. (2016). Metode Penelitian Kualitatif Untuk Ilmu Psikologi. Jakarta: PT.Raja Grafindo
} Persada. 
Penelitian ini dilaksanakan di PAUD Al-Amin Desa Pringgondani Kecamatan Bantur Kabupaten Malang dengan memiliki adanya visi dan misi utama untuk terwujudnya PAUD yang mampu mendidik anak menjadi insan yang berjiwa islami, mandiri, berilmu pengetahuan dan berakhlak mulia.

Penelitian ini, peneliti menggunakan teknik pengumpulan data berupa observasi, wawancara, dan dokumen. Pengecekan keabsahan data pada penelitian ini menggunakan trianggulasi. Oleh karena itu, penelitian menggunakan trianggulasi sumber data, trianggulasi teknik, dan trianggulasi waktu.

\section{HASIL DAN PEMBAHASAN}

Pertama, hasil temuan penelitian dari analisis yang ada pada proses hasil observasi, wawancara dan dokumentasi tentang implementasi sentra bermain peran untuk meningkatkan bahasa anak yang ada di PAUD Al Amin. Terlihat dari kegiatan belajar mengajar di sekolah yang telah menerapkan kegiatan bermain peran untuk mengatasi permasalahan yang terjadi pada kemampuan bahasa anak yang masih renda. Kemudian, kegiatan tersebut dilakukan secara rutin dengan tujuan untuk melatih kemampuan bahasa dan mengoptimalkan pembendaharaan kosa kata anak dalam keterampilan berbicara. Dimana, pembelajaran sentra bermain peran anak usia dini membutuhkan kematangan dari konsep materi, ruang, media, dan intrusksi guru dalam melatih sikap berekspresif anak yang sesuai dengan indikator keberhasilan yang telah di rancang. Selain itu, dampak dari pembelajaran sentra bermain peran dapat menunjukkan adanya interaksi anak dengan teman kelompoknya dalam berkomunikasi secara ekspresif yang jelas sesuai dengan perannya. Hal tersebut di perkuat adanya teori Piaget (dalam Asmawati,2015) bahwasannya konsep pembelajaran bermain peran disebut seperti belajar untuk bermain secara simbolik, mengelolah fantasi dan imajinasi melalui bermain drama sesuai dengan tahap usia anak ${ }^{5}$. Karena sikap rasa ingin tau anak dapat mensimulus anak dalam aktif berkomunikasi. Sehingga, pembelajaran ini akan menjadi alternatif kebutuhan dalam mengembangkan kemampuan bahasa anak.

Berdasarkan pemahaman tersebut, hasil refleksi dari temuan penelitian menunjukkan bahwa implementasi sentra bermain peran sangat ekfektif untuk meningkatkan kemampuan bahasa anak. Prosesnya menunjukkan adanya pembelajaran yang berdasarkan adanya kemauan anak untuk mengikuti setiap pijakan yang diinstruksikan oleh guru dan anak dapat memerankan peran yang diinginkan sesuai pilih secara berkelompok, disini anak mengembangkan interaksi dalam berkomunikasi dua arah walaupun anak masih butuh waktu untuk merespon secara ekspreksif.

Kedua, Peran guru dalam implementasi sentra bermain peran untuk meningkatkan bahasa anak. Hasil temuan disini guru melibatkan anak secara

\footnotetext{
${ }^{5}$ Luluk Asmawati, Pengelolaan Kegiatan Pengembangan Anak Usia Dini, cetakan XVII (Jakarta: Tangerang Selatan, Universitas Terbuka, 2015), halaman 8.10.
} 
keseluruhan dengan menentukan kelompok dalam bermain peran. Kemudian, adanya instruksi sebelum kegiatan dilakukan. Intruksi disini guru menjelaskan konsep materi yang akan diperankan, materi yang dikembangkan berupa tema profesi ${ }^{6}$. Sehingga keberadaan guru dalam proses pembelajaran dalam implementasi sentra bermain peran untuk meningkatkan bahasa anak juga sangat penting. Karena guru juga termasuk penentu dalam proses pembelajaran dalam implementasi sentra bermain peran untuk meningkatkan bahasa anak pada anak, guru tentu harus mampu menguasai dan paham pada setiap perkembangan bahasa pada anak. Sehingga, guru dapat memberikan fasilitas dan motivasi dalam perkembangan pendidikan anak usia dini. Peran guru dalam berinteraksi, pengasuhan, mengatur tekanan /stress, memberikan fasilitas, perencana, pengayaan, penanganan masalah, pembelajaran, bimbingan dan pemeliharaan ${ }^{7}$. Peran tersebut sangatlah penting karena untuk pembelajaran sentra bermain peran untuk meningkatkan bahasa anak. Kemampuan guru sebagai pemberian fasilitas pembelajaran yang dapat menunjang perkembangan anak.

Ketiga, Hasil temuan penelitian tentang proses pembelajaran bahasa melalui teknik penggunaan sentra bernain peran. Langkah-langkah pembelajaran bermain peran, meliputi langkah pertama, anak-anak di ajak untuk masuk ke dalam kelas sentra bermain peran, mula-mula ibu guru membacakan skenario sebelum anak-anak bermian peran. Skenario hari ini mengenai seorang nelayan yang sedang mencari ikan dan hasil tangkapannya di jual ke pasar ikan. Guru menjelaskan bagaimana proses nelayan untuk menangkap ikan dilaut dan sampai menjualnya di pasar. Semua dijelaskan dengan bahasa yang dapat dimerngerti anak-anak dengan mudah.

Langkah kedua, ketika guru telah selesai membacakan scenario. Lalu, ibu guru memberikan gambar sebagai rangsangan melalui proses bertanya " apakah anak-anak memahami cerita?" Hal ini dilakukan untuk mengasah keberanian anakanak dan juga bahasa juga sangat ditekankan agar anak-anak dapat menggutarakan pendapatnya sesuai pemahaman anak.

Langkah ketiga, guru memberi intruksi kepada peserta didik untuk membentuk kelompo dan mengambil peran yang sesuai dengan keinginan anak. Peran yang dibutuhkan, meliputi bapak nelayan, anak nelayan, petugas mercusuar, pedagang ikan, ibu yang memasak, dan mencuci piring. Hal ini bertujuan agar sentra bermain peran berjalan secara alamiah. Anak-anak mulai bercakap-cakap tentang ikan ada yang juga berpura-pura menjadi ibu yang sedang membeli ikan di pasar da nada juga yang berpura-pura menjadi pedagang ikan, suasana kelas berubah seolah-olah berada pada kehidupan nyata, nelayan yang menangkap ikan, petugas mercusuar yang mengetahui kondisi laut, nelayan yang menjual hasil tangkapannya, dan juga ada pedagang yang membeli hasil tangkapan para nelayan untuk dijual kepada ibu-ibu rumah tangga. Semua percakapan anak-anak di sentra

${ }^{6}$ Novan Ardy Wiyani, Konsep Dasar PAUD, cetakan 1(Jogjakarta: Gava Media, 2016), halaman 65
${ }^{7}$ Martinus Yamin dan Jamilah Sabri Sanan, Panduan PAUD, (Jakarta: Refrensi, 2013) halaman 32 
bermain peran sangat membantu anak yang masih cadel untuk lebih lancar dalam berbicara.

Hal ini dibuktikan dengan hasil wawancara dengan fungsi pembelajaran di sentra bermain peran adalah mengasah kemampuan anak usia 4-5 tahun yakni mengasah kemampuan bahasa, kognitif karena dalam sentra ini berbagai jenis permainan banyak disediakan. Dan sentra ini merupakan sentra yang paling diminati oleh anak didik di PAUD Al Amin. Setelah, anak-anak selesai bermain dengan perannya masing-masing saatnya anak-anak membereskan mainannya dan duduk melingkar untk melakukan refleksi (recalling). Untuk mengevaluasi perkembangan kemampuan berbahasa anak melalui kegiatan yang telah dilakukan. Jika, di rasa masih ada anak yang belum meningkat kemampuan bahasanya. Maka langka yang harus di ambil guru dalam meningkatkan kemampuan tersebut dengan teknik menerapkan kegiatan bermain peran dengan tema yang berbeda.

Berdasarkan hasil analisa data yang telah diperoleh dalam penelitian kualitatif menunjukkan adanya pembelajaran dalam implementasi sentra bermain peran untuk meningkatkan bahasa anak secara tepat. Hal ini dapat di lihat dari pola pembiasaan yang diberikan guru dalam merancang pembelajaran kepada anak usia dini di PAUD Al Amin menunjukkan adanya pengurangan jumlah terhadap anak cadel dan penambahan pembendaharaan kosa kata pada anak. Karena guru menggunakan proses pembelajaran dalam implementasi sentra bermain peran dengan metode pendekatan secara personal kepada anak. Teknik belajar dilakukan secara terus-menerus dengan tema yang berbeda. Proses pembelajaran tersebut dapat diterapkan di lingkungan rumah dalam melatih kedekatan anak dengan guru dan kedekatan orangtua dengan anak dalam berkomunikasi. Sehingga, proses adanya perkembangan anak dalam kemampuan bahasa anak ditentukan oleh rancangan kegiatan yang dapat menarik perhatian anak, proses belajar melibatkan anak dengan pemberian fasilitas media dan ruang belajar anak, dan adanya kerjasama guru dan orangtua dalam menciptakan, mengontrol dan mengarahkan pola belajar yang lebih menyenangkan.

\section{SIMPULAN DAN SARAN}

Berdasarkan hasil temuan penelitian, maka peneliti dapat merumuskan kesimpulan sebagai berikut pertama, implementasi sentra bermain peran untuk meningkatkan bahasa anak. hasil temuan penelitian menunjukkan bahwa anak PAUD yang ada di PAUD Al Amin dalam proses pembelajarannya menunjukkan adanya pembelajaran dan implementasi sentra bermain peran dapat meningkatkan bahasa pada anak, ditunjukkan dengan adanya peningkatan jumlah anak cadel dan penambahan kosa kata baru bagi anak untuk menggutarakan pendapatnya saat dilakukan recalling, dapat di ajak komunikasi dua arah walaupun anak masih butuh waktu untuk merespon. Kedua, peran guru dalam implementasi sentra bermain peran untuk meningkatkan bahasa anak. hasil temuan penelitian menunjukkan adanya pembelajaran yang tepat hal ini dapat dilihat dari pola pembiasaan yang 
diberikan guru kepada anak menunjukkan adanya pembelajaran yang seimbang dalam implementasi sentra bermain peran untuk meningkatkan bahasa pada anak. Karena guru menggunakan proses penanganannya dengan metode pendekatan personal kepada anak PAUD. Sehingga kedekatan anak dengan guru seperti kedekatan orangtua dengan anak. Dan dalam menyampaikan suatu informasi guru memberikan informasi tersebut dengan cara diulang-ulang sehingga anak dapat memahami satu informasi tersebut. Ketiga, proses pembelajaran bahasa melalui melalui teknik penggunaan sentra bermain peran Proses dimulai dengan anak masuk ke dalam kelas sentra bermain peran, kemudian ibu guru membacakan skenario permianan serta memberikan gambar sebagai upaya untuk merangsang anak agar lebih memahami alur cerita. Anak diberikan peran masing-masing dan diberikan kebebasan untuk memilih peran sesuai keinginan anak, anak menjalankan perannya masing-masing. Setelah perannya selesai anak diminta untuk menceritakan kembali peran apa yang mereka ambil dan bagaimana menjalankannya, semua percakapan anak di sentra bermian peran sangat membantu anak yang masi cadel untuk lebih lancar dalam berbicara.

Adapun saran-saran yang dikemukakan, sebagai berikut bagi sekolah, pada pembelajaran dalam implementasi sentra bermain peran untuk meningkatkan bahasa pada anak keberadaan guru juga memiliki peran yang sangat penting. Sehingga sekolah diharapkan dapat bekerja sama dengan orangtua agar pembelajaran dalam implementasi sentra bermain peran untuk meningkatkan bahasa pada anak dapat terbangun dengan sebaik baiknya. Bagi guru, dalam hal memenuhi standar kualifikasi guru yang ada, diharapkan agar ada salah satu guru yang paham tentang tumbuh kembang anak. Mengingat anak perkembahan bahasa anak PAUD yang harus ditangani khusus. Bagi orangtua, keluarga adalah lingkungan yang paling dekat dengan anak, diharapkan orangtua dapat menjadi motifator dan selalu memberikan dorongan dan semangat kepada anak. Agar tumbuh dan kembang bahasa anak juga belangsung dengan optimal.

\section{DAFTAR RUJUKAN}

Isjoni (2014). Pembelajaran Anak Usia Dini. Bandung: ALFABETA

Suryadi dan Ulfah. M (2015). Konsep Dasar PAUD. Bandung: Remaja Rosdakarya Hildayani, R., (2016). Psikologi Perkembangan Anak. Jakarta: Universitas Terbuka, Tanggerang Selatan

Gunarti, W., (2014). Metode Perkembangan Perilaku dan Kemampuan Dasar Anak Usia Dini. Jakarta: Universitas Terbuka, Tanggerang Selatan

Asmawati, L., (2015). Pengelolaan Kegiatan Pengembangan Anak Usia Dini. Jakarta: Universitas Terbuka, Tanggerang Selatan

Hanurawan, F. (2016). Metode Penelitian Kualitatif Untuk Ilmu Psikologi. Jakarta: PT.RajaGrafindo Persada. 
Hasan, M., (2009). Pendidian Anak Usia Dini. Jogjakarta: Diva Press

Fatimah, E., (2010). Psikologi Perkembangan. Bandung: Pustaka Setia

Rahman, H. S (2002). Konsep Dasar Pendidikan Anak Usia Dini. Jogjakarta: PGTKI Press

Wiyni, N. Ardy (2016). Konsep Dasar PAUD. Jogjakarta: Gava Media

Salvin, R. E (2011). Psikologi Pendidikan. Jakarta: PT Indeks

Yusuf, S. dan Nani M. S.(2011). Perkembangan Peserta Didik. Jakarta: Rajawali Press

Sugiyono (2010). Metode Penelitian Kualitatif, Kuantitatif dan R\&D. Bandung: Alfabeta

Sukmanadinata, N. S., (2010). Metode Penelitian Pendidikan. Jakarta: Remaja Rosdakarya 